\title{
Secretion of Inhibin during the Estrous Cycle in the Female Asian Elephant (Elephas maximus)
}

\author{
Saroch KAEWMANEE ${ }^{1,2)}$, Gen WATANABE ${ }^{1,2)}$, Miori KISHIMOTO ${ }^{2)}$, Wan Zhu JIN ${ }^{2)}$, Yuki YAMAMOTO ${ }^{1,2)}$, \\ Tatsuya YAMAMOTO ${ }^{1,2)}$, Kentaro NAGAOKA ${ }^{2)}$, Etsuo NARUSHIMA ${ }^{3)}$, Teruyuki KOMIYA ${ }^{4)}$ and Kazuyoshi TAYA ${ }^{1,2) *}$ \\ ${ }^{1)}$ Department of Basic Veterinary Science, The United Graduate School of Veterinary Sciences, Gifu University, Gifu 501-1193, \\ ${ }^{2)}$ Laboratory of Veterinary Physiology, Department of Veterinary Medicine, Faculty of Agriculture, Tokyo University of Agriculture and \\ Technology, Tokyo 183-8509, ${ }^{3)}$ Tama Zoological Park, Tokyo 191-0042 and ${ }^{4)}$ Ueno Zoological Gardens, Tokyo 110-8711, Japan
}

(Received 18 June 2010/Accepted 17 August 2010/Published online in J-STAGE 31 August 2010)

\begin{abstract}
To define the source of circulating inhibin in female Asian elephants, the immunolocalizations of the inhibin $\alpha, \beta_{A}$ and $\beta_{\mathrm{B}}$ subunits, $3 \beta$-hydroxysteroid dehydrogenase ( $3 \beta$-HSD), aromatase cytochrome $\mathrm{P} 450$ (P450arom) and cytochrome $17 \alpha$-hydroxylase P450 $(\mathrm{P} 450 \mathrm{c} 17)$ were investigated. Concentrations of immunoreactive (ir-) inhibin, progesterone and follicle-stimulating hormone (FSH) during the estrous cycle were measured by radioimmunoassay. Inhibin immunoreactivity in follicular fluid and homogenate of corpora lutea was also measured. Immunolocalizations of inhibin subunits, $3 \beta$-HSD, P450arom and P450c17 were detected in the granulosa cells of antral follicles and luteal cells. The follicular fluid contained high levels of ir-inhibin and bioactive inhibin. The homogenate of corpora lutea also contained ir-inhibin. Serum ir-inhibin remained at low levels during the early non-luteal phase, began to increase from the late non-luteal phase and continued to increase during the early luteal phase. Serum ir-inhibin showed maximal levels in the middle of the luteal phase and gradually decreased to baseline three weeks prior to progesterone decline. The serum ir-inhibin levels were positively correlated with progesterone throughout the estrous cycle. On the other hand, ir-inhibin was negatively correlated with FSH during the late non-luteal and early luteal phases. These findings strongly suggest that the corpus luteum is one of the sources of inhibin as well as granulosa cells in the Asian elephant.
\end{abstract}

KEY WORDS: Asian elephant, corpora lutea, follicles, inhibin, progesterone.

J. Vet. Med. Sci. 73(1): 77-82, 2011

The efficiency of reproduction of the Asian elephant (Elephas maximus) in captivity has become a major concern over the past decades. However, captive breeding programs worldwide have encountered with limited success. Hence, more effort is needed to improve the captive breeding strategies and understand the fundamental reproductive physiology of elephants. The normal estrous cycle duration of elephants has an exceptionally long range, from 14 to 18 weeks. It consists of a luteal phase that is characterized by high progesterone concentrations and ranges between 10-14 weeks and an interluteal (follicular) phase that lasts between 3 and 6 weeks [22]. During the follicular phase, 2 surges of luteinizing hormone (LH) occur. The first LH surge is anovulatory $(\mathrm{anLH})$, whereas ovulation occurs three weeks later around $24 \mathrm{hr}$ after the second LH (ovLH) surge [1, 2, 9].

Inhibins, heterodimeric glycoprotein hormones, are composed of an $\alpha$-subunit and one of two $\beta$-subunits $\left(\beta_{\mathrm{A}}\right.$ or $\left.\beta_{\mathrm{B}}\right)$, with the $\alpha-\beta_{\mathrm{A}}$ and $\alpha-\beta_{\mathrm{B}}$ dimers forming inhibin $\mathrm{A}$ and inhibin $\mathrm{B}$, respectively. Inhibins are produced mainly by the granulosa cells of ovarian follicles when the follicles develop from the small antral to preovulatory stages and suppress follicle stimulating hormone (FSH) secretion [12], such as in rats $[10,13]$, golden hamsters [11, 17], guinea pigs $[19,20]$, sheeps [3], goats [7, 8], monkeys [18], mares

\footnotetext{
* Correspondence to: TAya, K., Laboratory of Veterinary Physiology, Department of Veterinary Medicine, Faculty of Agriculture, Tokyo University of Agriculture and Technology, 3-5-8 Saiwaicho, Fuchu, Tokyo 183-8509, Japan. e-mail: taya@cc.tuat.ac.jp
}

$[15,16]$ and ducks $[29,30]$. Although changes in circulating inhibin in elephants have been reported [1,2], its cellular sources of ovaries have not been studied yet.

This study was conducted to determine the secretory pattern of inhibin and the cellular source of inhibin in ovaries of Asian elephants. In addition, the relationships among inhibin, FSH and progesterone during the estrous cycle were investigated.

\section{MATERIALS AND METHODS}

Animals and blood sampling: Three nulliparous female Asian elephants (Elephas maximus) named Asha (year of birth: 1977), Daya (year of birth: 1977) and Jumbo (year of birth: 1944) were used as the subjects in this study. Asha and Daya were used for evaluating circulatory hormonal levels from 1989 to 1994, while ovarian tissues from Jumbo were used for histological, immunohistochemical, bioassay and immunoreactivity investigations. The animals were housed in Ueno Zoological Gardens (Tokyo, Japan), fed twice daily and provided with water ad libitum.

Blood samples $(10 \mathrm{~m} l)$ were collected at a weekly interval between $0800 \mathrm{hr}$ and $0900 \mathrm{hr}$ from ear veins without anesthesia for 55 months (October 1989-April 1994). Blood was centrifuged at $1700 \times g$ for $15 \mathrm{~min}$ to separate serum from blood cells. Sera were collected and stored at $-20^{\circ} \mathrm{C}$ until hormonal analysis.

Ovarian tissue collection: Ovaries were collected from Jumbo at autopsy after accidental death ( 56 years old). Fol- 
licular fluid was collected by aspiration using a needle with a tuberculin syringe and then stored at $-80^{\circ} \mathrm{C}$ until bioactivity and immunoreactivity analyses. The remaining ovarian tissues were immediately fixed in $4 \%$ paraformaldehyde (Sigma Chemical Co., St. Louis, MO, U.S.A.) in $0.05 \mathrm{M}$ PBS (pH 7.4), dehydrated in a graded series of ethanol, embedded in paraffin and cut into sections $6-\mu \mathrm{m}$ thick.

Immunohistochemistry: Immunohistochemical staining for inhibin subunits and steroidogenic enzymes was carried out as described previously $[17,26]$. The primary antibodies used were as follows: rabbit polyclonal antibodies against 1) [Tyr30] porcine inhibin $\alpha$ chain $(1-30) \mathrm{NH}_{2}, 2$ ) cyclic inhibin $\left.\beta_{A}(81-113) \mathrm{NH}_{2}, 3\right)$ cyclic inhibin $\beta_{B}(80-$ 112) $\mathrm{NH}_{2}$, 4) $3 \beta$-hydroxysteroid dehydrogenase ( $3 \beta \mathrm{HSD}$ ), 5) cytochrome $\mathrm{P} 450$ aromatase (P450arom) and 6) porcine testicular cytochrome $17 \alpha$-hydroxylase P450 (P450 c17). The antibodies for the inhibin $\beta$ subunits were kindly supplied by Dr. Wylie Vale (The Salk Institute for Biological Studies, San Diego, CA, U.S.A.). The antibodies for $3 \beta \mathrm{HSD}, \mathrm{P} 450 \mathrm{c} 17$ and P450arom were kindly supplied by Dr. J. I. Mason (Green Center for Reproductive Sciences, University of Texas, Southern Medical Center, Dallas, TX, U.S.A.), Dr. D. C. Johnson (Department of Gynecology and Obstetrics and Physiology, University of Kansas Medical Center, Kansas City, KS, U.S.A.), and Dr. Y. Osawa (Medical Foundation of Buffalo, Buffalo, NY, USA), respectively.

Immunoreactive (ir-) inhibin RIA: Concentrations of irinhibin in elephant samples were measured by RIA based on a previously described bovine inhibin RIA [6] using antisera against bovine inhibin (TNDH-1) and bovine $32-\mathrm{kDa}$ inhibin for both iodination and the standard, respectively. The intra- and interassay coefficients of variation were $4.0 \%$ and $6.2 \%$, respectively.

FSH RIA: The serum concentration of FSH was measured by a heterologous RIA using a method described previously [25]. The antiserum employed was an anti-ovine FSH (NIDDK-H-31). The iodinated preparation was rat FSH-I5. Results are expressed in terms of NIDDK rat FSH-RP-2. The intra- and interassay coefficients of variation were 7.8 and $8.5 \%$, respectively.

Progesterone RIA: The serum concentrations of progesterone were determined by double-antibody RIA systems using ${ }^{125}$ I-labeled radioligands as described previously [24]. Antisera against progesterone [5] were kindly provided by Dr. G. D. Niswender (Animal Reproduction and Biotechnology, Colorado State University, Fort Collins, CO, U.S.A.).

Bioactivity of inhibin: The bioassay of inhibin in steroidfree elephant follicular fluid was assessed by means of suppression of FSH secretion by the rat pituitary cell culture system as previously described [23]. A partially purified bovine follicular fluid inhibin preparation obtained after immunoaffinity chromatography (AF-BF) was used for the standard [14].

Hormonal data analysis: Thirteen complete cycles from two elephants were used to calculate mean levels of all hor- mone relationships during the estrous cycle according to our previous paper [22]. In order to profile the changes of hormonal patterns, week 0 was determined from the week before the first elevation of serum concentrations of progesterone higher than $0.2 \mathrm{ng} / \mathrm{ml}$ during the estrous cycle. Week 0 of each cycle corresponded to the week just before ovulation, which was characterized as the state exhibiting the lowest concentration of progesterone in the serum. The luteal phase included those weeks from the initial rise of progesterone (week 1) to the week in which the level returned to baseline (week 13).

Statistical analysis: All hormonal data are presented as means \pm standard errors of the mean (SEM). The data were normally distributed, and therefore Pearson's correlations were used to test the relationships among hormones throughout the estrous cycle by using the Statistical Package for the Social Sciences (SPSS 18.0, SPSS, Inc., Chicago, IL, U.S.A.). Statistical evaluation was performed by repeated measured ANOVA, and differences of hormone concentrations during the estrous cycle were analyzed using a posthoc test (Bonferroni/Dunn). $P<0.05$ was considered to indicate a significant difference.

\section{RESULTS}

Characterization of inhibin RIA: Inhibin RIA doseresponse curves obtained with follicular fluid, peripheral sera and the homogenate of corpora lutea of the Asian elephants are shown in Fig. 1. They showed a parallel doseresponse relationship among the bovine inhibin standard, elephant follicular fluid, elephant sera and homogenate of elephant corpora lutea. These results indicated that this inhibin RIA system could be applicable to measurement of the ir-inhibin level in Asian elephants.

Inhibin bioactivity: The results of the inhibin bioassay using the rat pituitary cells culture system are shown in Fig. 2. The secretion of FSH from cultured rat anterior pituitary cells was clearly suppressed in a dose-dependent manner by

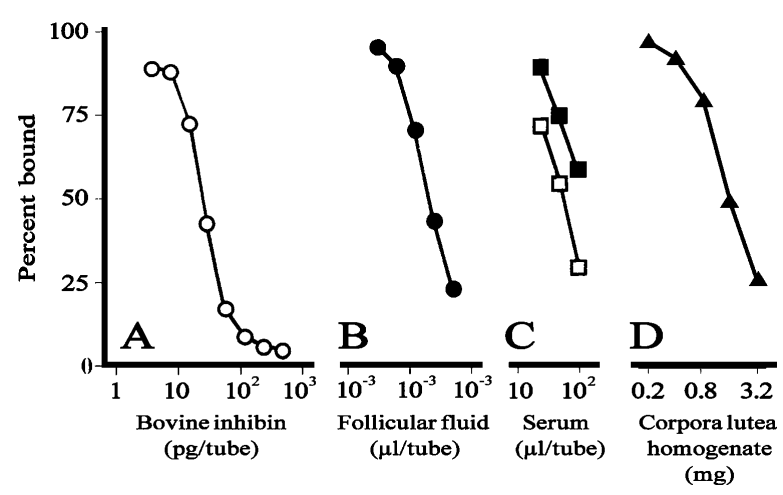

Fig. 1. Radioimmunoassay dose-response curves of follicular fluid and sera using ${ }^{125} \mathrm{I}$ - labeled bovine $32-\mathrm{kDa}$ inhibin as a tracer. Each value represents the mean of triplicate determinations of bovine inhibin ( $\bigcirc$ ), follicular fluid $(\bigcirc)$, sera ( $\square$ and

: luteal and follicular phase, respectively) and corpora lutea homogenate $(\boldsymbol{\Delta})$ of Asian elephants. 

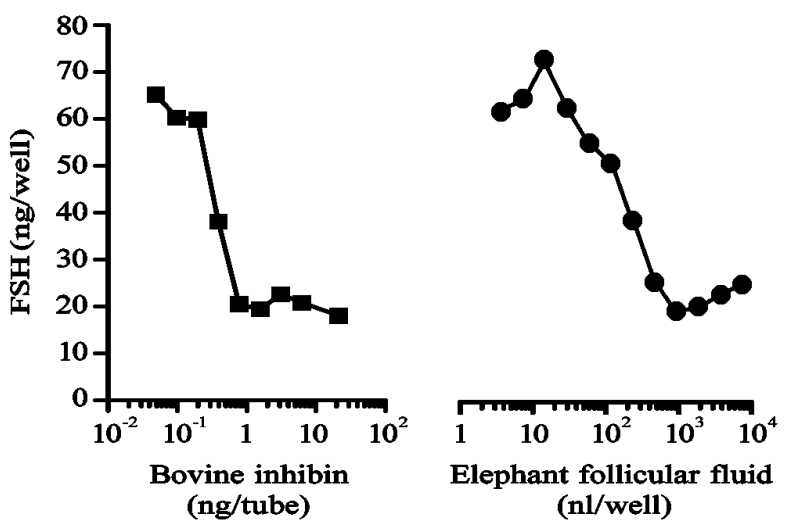

Fig. 2. Dose-response curves of the inhibin bioassay of Asian elephant follicular fluid using the rat pituitary cell culture system. Each value represents the mean of triplicate determinations of bovine inhibin $(\boldsymbol{Q})$ and follicular fluid of antral follicles of an Asian elephant (O).

the addition of serial dilutions of elephant follicular fluid $(0.001-1.0 \mu \mathrm{L})$; this is the same as the result for the bovine inhibin standard.

Changes in serum concentrations of ir-inhibin, progesterone and FSH: The serum concentrations of ir-inhibin, progesterone and FSH are shown in Fig. 3 as sequential patterns throughout the estrous cycle of two Asian elephants. Serum ir-inhibin remained at a low level until week -2, gradually increased from week -1 and continued to increase until week 6 (Fig. 3A). The serum concentrations of ir-inhibin remained elevated in week 7 and gradually declined to baseline by week 10 .

The serum concentrations of progesterone were at their lowest in week 0 and steadily increased from week 1 to week 7 (Fig. 3B). The peak of progesterone remained unchanged until week 9 and then declined thereafter. The progesterone in circulation was positively correlated with irinhibin ( $\mathrm{n}=290, \mathrm{r}=0.648, P<0.005)$, though the levels of irinhibin started to decline 3 weeks before progesterone.

The serum concentrations of FSH were highest in week 2 and lowest in week 3, respectively (Fig. 3C). Then, the serum concentrations of FSH significantly increased from the week 3 to $5(p<0.05)$ and then remained stable until the week 16. They showed significant negative correlation with ir-inhibin during week -2 and week $2(\mathrm{n}=86, \mathrm{r}=-0.797$, $P<0.05)$.

Immunohistochemistry of inhibin subunits and steroidogenic enzymes: Examination of the histological architecture of an Asian elephant ovary revealed the presence of healthy antral follicles and corpora lutea. The immunoreactivity of the inhibin $\alpha$ (Fig.4B and F), $\beta_{\mathrm{A}}$ (Fig. $4 \mathrm{C}$ and G) and $\beta_{\mathrm{B}}$ (Fig. $4 \mathrm{D}$ and $\mathrm{H}$ ) subunits showed clear positive staining in both granulosa cells of antral follicles (Fig. 4B-D) and lutein cells (Fig. 4F-H). However, the theca cells of antral follicles stained negatively for the inhibin subunits (Fig. 4BD). Regarding steroidogenic enzymes, $3 \beta \mathrm{HSD}$ (Fig.5B and F), P450arom (Fig.5C and G) and P450 c17 (Fig.5D and H)
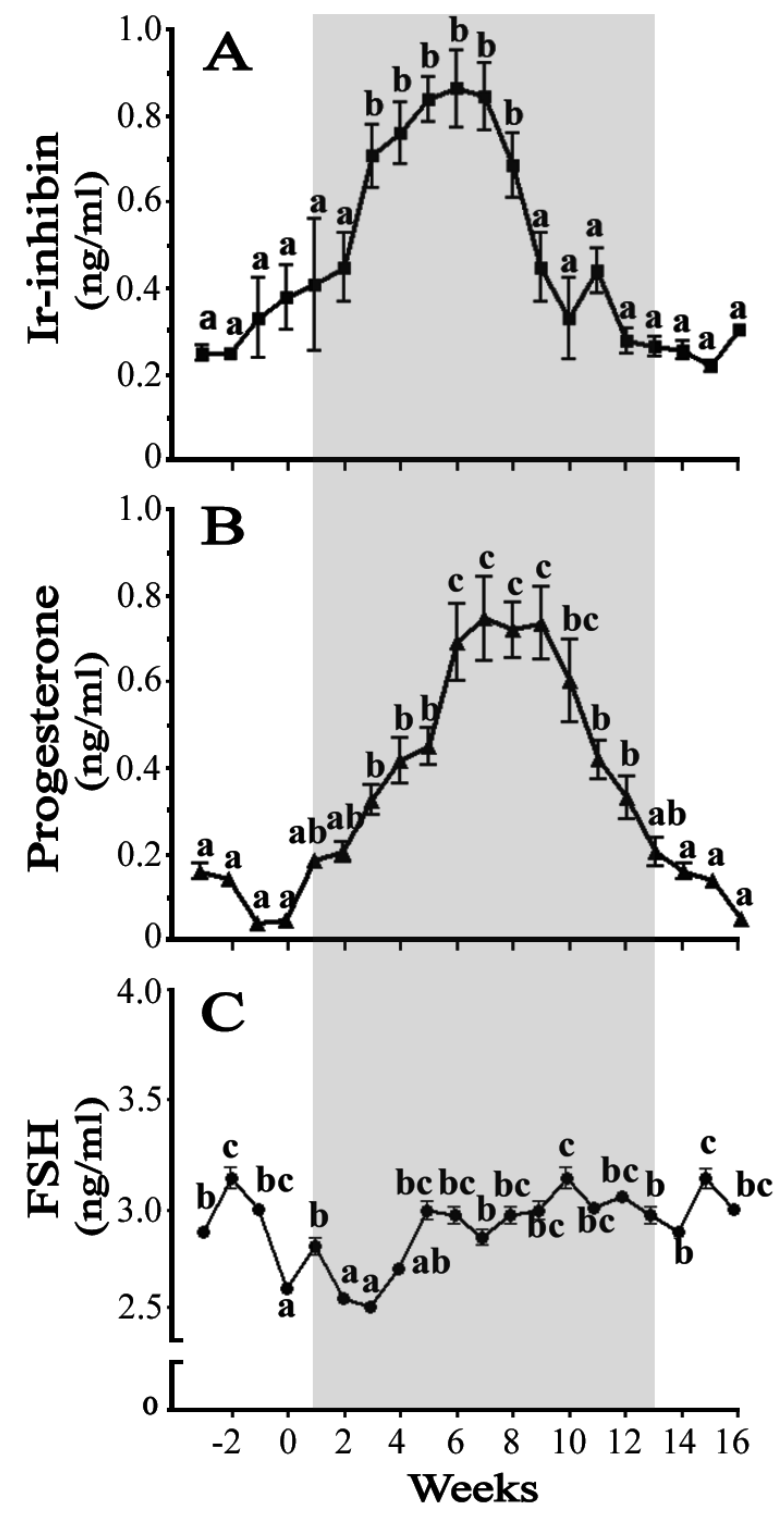

Fig. 3. Sequential changes in serum concentrations of ir-inhibin (A), progesterone (B) and FSH (C) in thirteen complete estrous cycles from two Asian elephants synchronized by aligning the values of progesterone. Data were normalized by designating week 0 as the week before the first elevation of the serum concentrations of progesterone higher than $0.2 \mathrm{ng} / \mathrm{m} l$ in each cycle of two animals. The shaded period (week 1 to 13) corresponds to the luteal phase. Values from weeks $14-16$ are the same as those of weeks -3 to -1 . Results are expressed as means \pm SEM. Different superscripts indicate significant differences $(p<0.05)$.

were localized in both granulosa cells and theca cells of antral follicles (Fig. 5B-D) and lutein cells (Fig. 5F-H).

\section{DISCUSSION}

The ovarian activities of mammalian species including elephants have been shown to depend on the hypothalamic- 

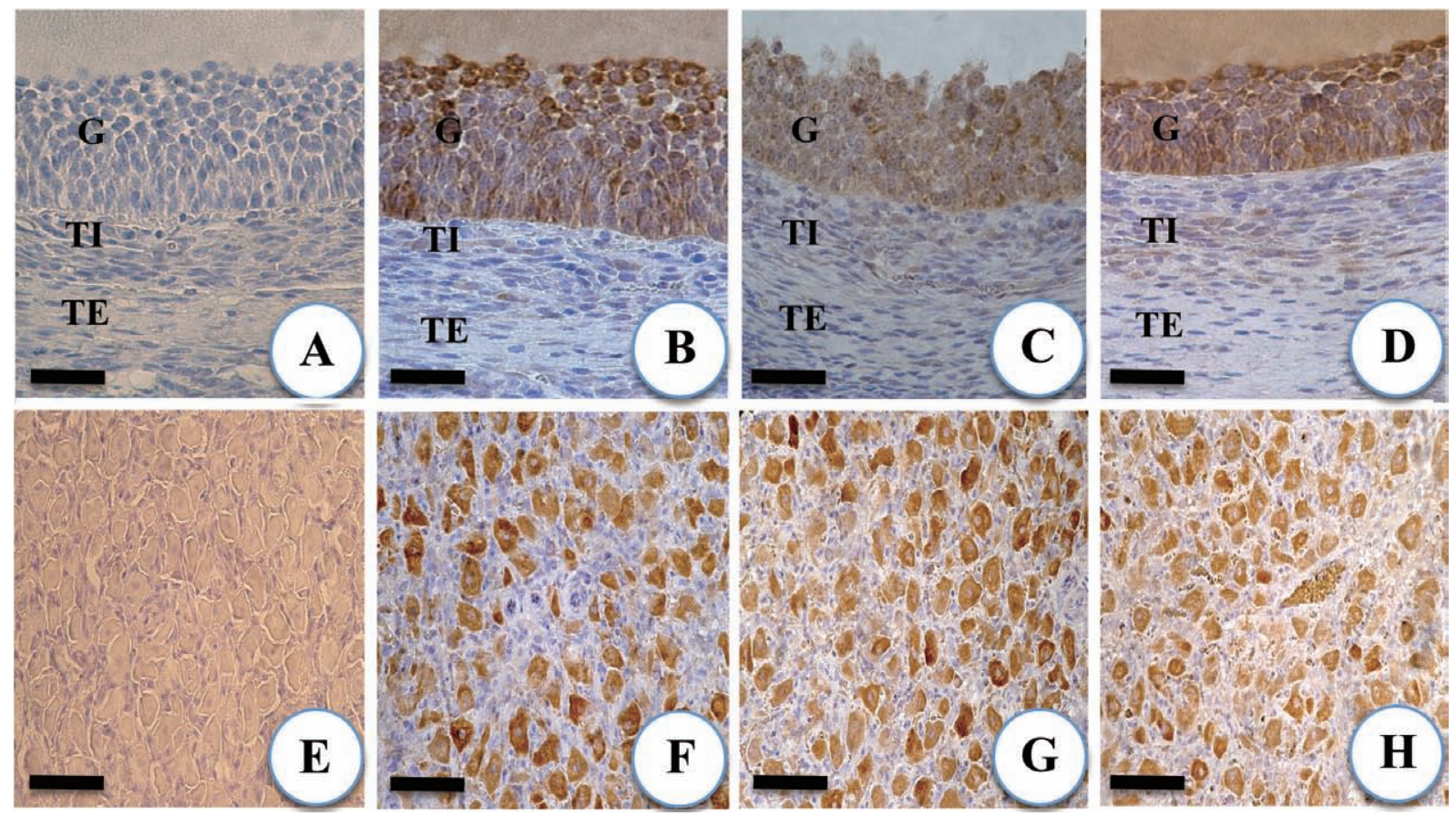

Fig 4. Immunohistochemical localizations of the inhibin $\alpha, \beta_{\mathrm{A}}$ and $\beta_{\mathrm{B}}$ subunits in antral follicles and the corpus luteum of the Asian elephant. Stained with inhibin $\alpha$ subunit $(\mathrm{B}, \mathrm{F})$, inhibin $\beta_{\mathrm{A}}$ subunit $(\mathrm{C}, \mathrm{G})$ or inhibin $\beta_{\mathrm{B}}$ subunit $(\mathrm{D}, \mathrm{H})$ and with hematoxylin and eosin. As a negative control (A, E), normal rabbit serum was substituted for the first antibodies. Scale bar $=100 \mu \mathrm{m}$.
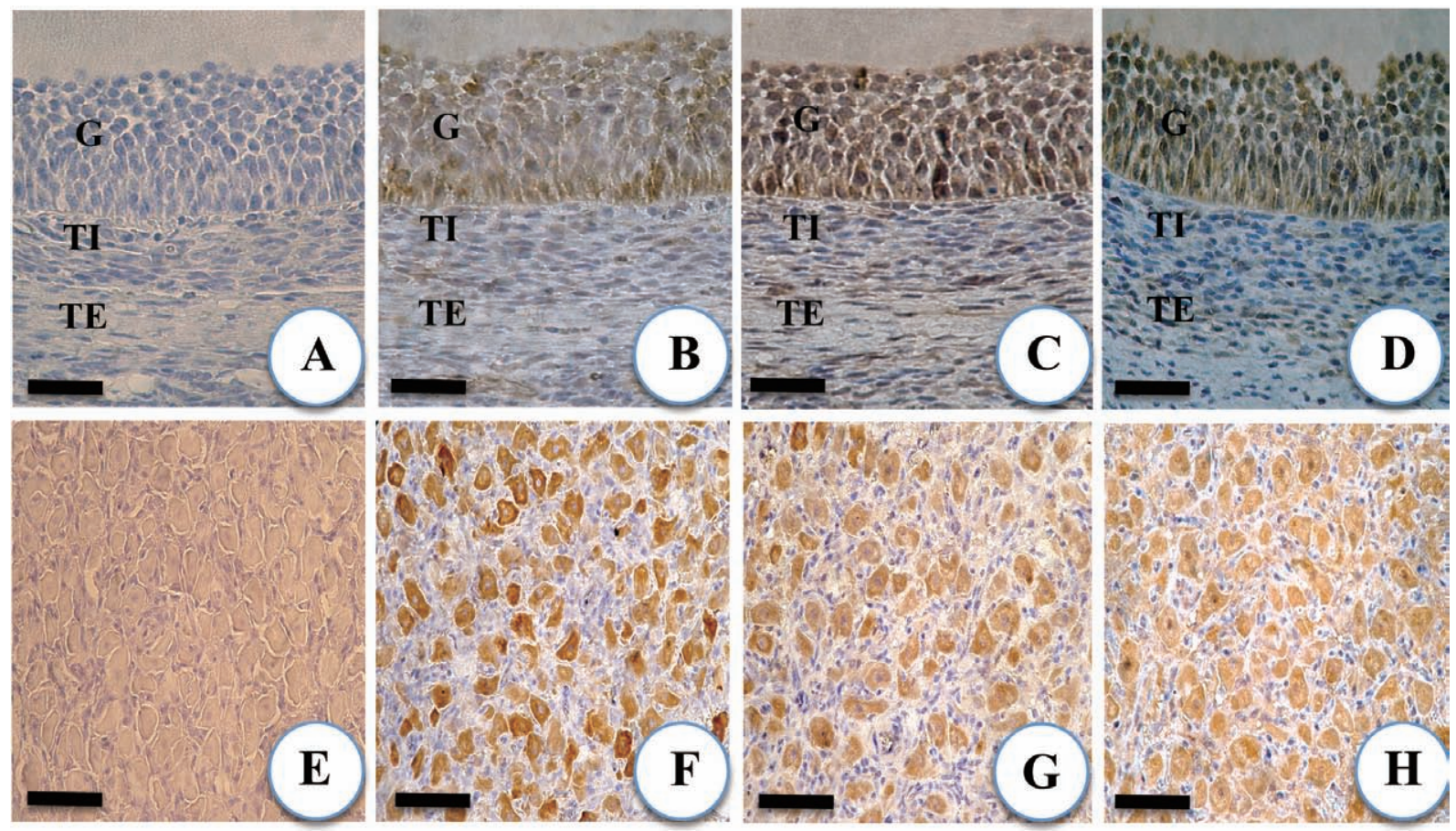

Fig. 5. Immunohistochemical localization of $3 \beta$-hydroxysteroid dehydrogenase ( $3 \beta \mathrm{HSD}$ ), cytochrome $\mathrm{P} 450$ aromatase (P450arom) and cytochrome $17 \alpha$-hydroxylase P450 (P450 c17) in antral follicles and the corpus luteum of the Asian elephant. Stained with $3 \beta \mathrm{HSD}$ (B, F), P450Arom (C, G) or P450c17 (D, H) and stained with hematoxylin and eosin. As a negative control (A, E), normal rabbit serum was substituted for the first antibodies. Scale bar $=100 \mu \mathrm{m}$. 
pituitary-ovarian relationships, with a strong emphasis on the feedback controlling role of inhibin on pituitary secretion of FSH [12]. However, the cellular source of inhibin in elephants is still unclear. The present study clearly demonstrated for the first time the localization of the inhibin $\alpha, \beta_{A}$ and $\beta_{B}$ subunits in both granulosa cells of antral follicles and lutein cells in the ovary of the Asian elephant. The positive immunoreactivity of granulosa cells of antral follicles for all inhibin subunits is in agreement with previous reports, such as in rats $[10,13]$, golden hamsters $[11,17]$, monkeys [18], guinea pigs $[19,20]$, sheeps [3], goats $[7,8]$ and mares $[15$, 16]. The presence of the inhibin $\alpha, \beta_{A}$ and $\beta_{B}$ subunits in lutein cells of the corpus luteum is the similar findings to humans $[21,27,28]$, and monkeys [4, 18]. The present study strongly suggests that corpora lutea as well as follicular granulosa cells are the major sources of inhibin during the estrous cycle in this species. The immunolocalization of $3 \beta \mathrm{HSD}, \mathrm{P} 450$ arom and $\mathrm{P} 450 \mathrm{c} 17$ in both granulosa cells and lutein cells of Asian elephants also suggests that the granulosa cells and corpora lutea of the Asian elephants are able to synthesize progesterone, androgen and estrogen.

Immunoreactive inhibin was detected in both follicular fluid and the homogenate of corpora lutea of the Asian elephants. These findings together with the immunohistochemical results emphasized the fact that both antral follicles and corpora lutea in the ovaries of the Asian elephants are able to secrete inhibin. In addition, the follicular fluid from antral follicles of an Asian elephant clearly suppressed FSH secretion by rat pituitary cells cultured in vitro, indicating that elephant follicles are able to secrete bioactive inhibin. The present study demonstrated that ir-inhibin was detectable in the circulation throughout the estrous cycle of the Asian elephants.

In the present study, circulating ir-inhibin showed a significant negative correlation with FSH between week -2 and week 2 (the non-luteal and early luteal phases), whereas there were no significant correlations in any other period during the whole estrous cycle. Although mechanism responsible for the different pattern of circulating ir-inhibin and FSH in the period of week -2 and week 2 was not clear, ovarian events in the period might be important.

It is possible that rapid development of a dominant follicle, ovulation and formation of corpora lutea occur during the period of week -2 and week 2. Brown et al. reported that the serum concentration of inhibin was negatively correlated with FSH during the non-luteal phase in the female Asian elephants $[1,2]$. However, it is unclear why there was no significant negative correlation between ir-inhibin and FSH during the mid-luteal phase, which showed both high levels of ir-inhibin and FSH in the present study.

The serum levels of ir-inhibin showed a gradual increase from two weeks prior to the week of ovulation (week 0 ) to week 6 and returned to the basal levels around three weeks prior to the reductions of progesterone. In addition, the serum levels of ir-inhibin paralleled those of progesterone. These results further suggest that the large preovulatory antral follicles are the sources of ir-inhibin during the late follicular phase and that corpora lutea are the major source of ir-inhibin during the luteal phase.

In conclusion, the cellular localizations of the inhibin $\alpha$, $\beta_{\mathrm{A}}$ and $\beta_{\mathrm{B}}$ subunits were detected in the granulosa cells of antral follicles and lutein cells in the ovary of a female Asian elephant. The positive correlation among the ir-inhibin and progesterone levels in circulation also strongly suggest that the granulosa cells of antral follicles and corpora lutea are the major source of circulating inhibin during the estrous cycle in Asian elephants.

ACKNOWLEDGMENTS. We are grateful to Dr. A. F. Parlow (National Hormone and Peptide Program, HarborUCLA Medical Center, Torrance CA, U.S.A.) for providing RIA materials of rat and ovine FSH, Dr. G.D. Niswender (Animal Reproduction and Biotechnology Laboratory, Colorado State University, Fort Collins, CO, U.S.A.) for providing antisera to progesterone (GDN 337), Dr. Wylie Vale (The Salk Institute for Biological Studies, San Diego, CA, U.S.A.) for providing the antisera to inhibin $\beta_{\mathrm{A}}$, and $\beta_{\mathrm{B}}$ subunits, Dr. J. I. Mason (Clinical biochemistry, The University of Edinburgh, The Queen's Medical Research Institute, Edinburgh, UK) for providing antisera to $3 \beta \mathrm{HSD}$, Dr. Y. Osawa (Medical Foundation of Buffalo, Buffalo, NY, U.S.A. for providing the antisera to P450arom and Dr. D. C. Johnson (Department of Gynecology and Obstetrics and Physiology, University of Kansas Medical Center, Kansas City, KS, U.S.A.) for providing antisera to cytochrome $17 \alpha$ hydroxylase P450 (P450 c17). This study was supported in part by The Inui Memorial Trust for Research on Animal Science.

\section{REFERENCES}

1. Brown, J. L., Citino, S. B., Bush, M., Lehnhardt, J. and Philips, L. G. 1991. Cyclic patterns of luteinizing hormone, folliclestimulating hormone, inhibin and progesterone secretion in the Asian elephant (Elephas maximus). J. Zoo Wildl. Med. 22: 4957.

2. Brown, J. L., Schmitt, D. L., Bellem, A., Graham, L. H. and Lehnhardt, J. 1999. Hormone secretion in the Asian elephant (Elephas maximus): characterization of ovulatory and anovulatory luteinizing hormone surges. Biol. Reprod. 61: 1294-1299.

3. Engelhardt, H., Smith, K. B., McNeilly, A. S. and Baird, D. T. 1993. Expression of messenger ribonucleic acid for inhibin subunits and ovarian secretion of inhibin and estradiol at various stages of the sheep estrous cycle. Biol. Reprod. 49: 281294.

4. Fraser, H. M., Smith, K. B., Lunn, S. F., Cowen, G. M., Morris, K. and McNeilly, A. S. 1992. Immunoneutralization and immunocytochemical localization of inhibin alpha subunits during the mid-luteal phase in the stump-tailed macaque. $J$. Endocrinol. 133: 341-347.

5. Gibori, G., Antczak, E. and Rothchild, I. 1977. The role of estrogen in the regulation of luteal progesterone secretion in the rat after day 12 of pregnancy. Endocrinology 100: 14831495 .

6. Hamada, T., Watanabe, G., Kokuho, T., Taya, K., Sasamoto, 
S., Hasegawa, Y., Miyamoto, K. and Igarashi, M. 1989. Radioimmunoassay of inhibin in various mammals. J. Endocrinol. 122: $697-704$.

7. Kandiel, M. M., Watanabe, G., Sosa, G. A., Abou El-Roos, M. E., Abdel-Ghaffar, A. E., Li, J. Y., Manabe, N., El Azab, A. E. and Taya, K. 2010. Profiles of Circulating Steroid Hormones, Gonadotropins, Immunoreactive Inhibin and Prolactin during Pregnancy in Goats and Immunolocalization of Inhibin Subunits, Steroidogenic Enzymes and Prolactin in the Corpus Luteum and Placenta. J Reprod. Dev. 56: 243-250.

8. Kandiel, M. M., Watanabe, G. and Taya, K. Ovarian expression of inhibin-subunits, $3 ß$-hydroxysteroid dehydrogenase and cytochrome $\mathrm{P} 450$ aromatase during the estrous cycle and pregnancy of goats. Exp. Anim. (in press).

9. Kapustin, N., Critser, J. K., Olsen, D. and Malven, P. V. 1996. Nonluteal estrous cycles of 3-week duration are initiated by anovulatory luteninizing hormone peaks in African elephants (Loxodonta africana). Biol. Reprod. 55: 1147-1154.

10. Kenny, H. A. and Woodruff, T. K. 2006. Follicle size class contributes to distinct secretion patterns of inhibin isoforms during the rat estrous cycle. Endocrinology 147: 51-60.

11. Kishi, H., Ohshima, K., Itoh, M., Tsukada, J., Arai, K. Y., Nakano, S., Watanabe, G. and Taya, K. 2002. Changes in expression of inhibin subunits in the cyclic golden hamster (Mesocricetus auratus) and the regulation of inhibin alpha subunit production by luteinizing hormone. Zoolog. Sci. 19: 225232.

12. Medan, M. S., Arai, K. Y., Watanabe, G. and Taya, K. 2007. Inhibin: Regulation of reproductive function and practical use in females. Anim. Sci. J. 78: 16-27.

13. Meunire, H., Cajander, S. B., Roberts, V. J., Rivier, C., Sawchenko, P. E., Hsueh, A. J. W. and Vale, W. 1988. Rapid changes in the expression of inhibin $\alpha-, \beta_{\mathrm{A}^{-}}$and $\beta_{\mathrm{B}}$-subunits in ovarian cell types during the rat estrous cycle. Mol. Endocrinol. 2: 1352-1363.

14. Miyamoto, K., Hasegawa, Y., Fukuda, M., Igarashi, M., Kangawa, K. and Matsuo, H. 1987. Isolation and characterization of porcine and bovine follicular fluid inhibins. pp. 47-59. In: Inhibin-Non-Steroidal Regulation of Follicle Stimulating Hormone Secretion (Burger, H. G., de Kretser, D., Findlay, J. K. and Igarashi, M. eds.), Raven Press, New York.

15. Nagamine, N., Numbo, Y., Nagata, S., Nagaoka, K., Tsunoda, N., Taniyama, H., Tanaka, Y., Tohei, A., Watanabe, G. and Taya, K. 1998. Inhibin Secretion in the Mare: Localization of Inhibin $\alpha, \beta_{\mathrm{A}}$ and $\beta_{\mathrm{B}}$ Subunits in the Ovary. Biol. Reprod. 59: 1392-1398.

16. Nagaoka, K., Arai, K., Nagamine, N., Nambo, Y., Nagata, S., Tanaka, Y., Shinbo, H., Taniyama, H., Tsunoda, N., Yamanouchi, K., Hondo, E., Yamada, J., Watanabe, G. and Taya, K. 2001. Expression of inhibin/activin subunits, aromatase and 3 b-hydroxysteroid dehydrogenase in various sized ovarian antral follicles of the mare. J. Equine Sci. 12: 77-83.

17. Otsuka, M., Kishi, H., Arai, K., Watanabe, G., Taya, K. and Greenwald, G. S. 1997. Temporal Changes in inhibin, steriod hormones, and steroidogenic enzymes during induced follicular atresia in the hypophysectomized cyclic hamster. Biol.

\section{Reprod. 56: 423-429.}

18. Schwall, R. H., Mason, A. J., Wilcox, J. N., Bassett, S. G. and Zeleznik, A. J. 1990. Localization of inhibin/activin subunit mRNAs within the primate ovary. Mol. Endocrinol. 4: 75-79.

19. Shi, F., Ozawa, M., Komura, H., Yang, P., Trewin, A. L., Hutz, R. J., Watanabe, G. and Taya, K. 1990. Secretion of ovarian inhibin and its physiologic roles in the regulation of folliclestimulating hormone secretion during the estrous cycle of the female guinea pig. Biol. Reprod. 60: 78-84.

20. Shi, F., Watanabe, G., Trewin, A. L., Hutz, R. J. and Taya, K. 2000. Localization of Ovarian Inhibin/Activin Subunits in Follicular Dominance during the Estrous Cycle of Guinea Pigs. Zoolog. Sci. 17: 1311-1320.

21. Smith, K. B., Millar, M. R., McNeilly, A. S., Illingworth, P. J., Fraser, H. M. and Baird, D. T. 1991. Immunocytochemical localization of inhibin alpha-subunit in the human corpus luteum. J. Endocrinol. 129: 155-160.

22. Taya, K., Komura, H., Kondoh, M., Ogawa, Y., Nakada, K., Watanabe, G., Sasamoto, S., Tanabe, K., Saito, K., Tajima, H. and Narushima, E. 1991. Concentrations of progesterone, testosterone and estradiol-17 $\beta$ in the serum during the estrous cycle of Asian elephants (Elephas maximus). Zoo. Biology. 10: 299-307.

23. Taya, K. and Sasamoto, S. 1988. Selective release of FSH in lactating rats during the period of follicular atresia induced by the administration of antiserum to LH-releasing hormone. $J$. Endocrinol. 118: 455-464.

24. Taya, K., Watanabe, G. and Sasamoto, S. 1985. Radioimmunoassay for progesterone, testosterone and estradiol- $17 \beta$ using ${ }^{125} \mathrm{I}$-iodohistamine radioligands. Jpn. J. Anim. Reprod. 31: 186-197.

25. Watanabe, G., Nozaki, M., Taya, K., Katakai, Y. and Sasamoto, S. 1990. Immunoreactive inhibin levels in peripheral blood during the breeding season in the female Japanese monkey. Bol. Reprod. 43: 196-201.

26. Weng, Q., Medan, M. S., Ren, L., Watanabe, G., Tsubota, T. and Taya, K. 2005. Immunolocalization of Steroidogenic Enzymes in the Corpus Luteum and Placenta of the Japanese Shiba Goat. J. Reprod. Dev. 51: 247-252.

27. Yamoto, M., Minami, S., Nakano, R. and Kobayashi, M. 1992. Immunolocalization of inhibin/activin subunits in human ovarian follicles during the menstrual cycle. J. Clin. Endocrinol. Metab. 74: 989-993.

28. Yamoto, M., Minami, S. and Nakano, R. 1991. Immunohistochemical localization of inhibin subunits in human corpora lutea during menstrual cycle and pregnancy. J. Clin. Endocrinol. Metab. 73: 470-477.

29. Yang, P. X., Arai, K. Y., Jin, W. Z., Watanabe, G., Goome, N. P. and Tya, K. 2001. Preovulatory follicles in the ovary as the source of circulating inhibin in the duck. Gen. Comp. Endocrinol. 121: 156-162.

30. Yng, P., Medan, M. S., Aai, K. Y., Watanabe, G. and Taya K. 2005. Plasma concentrations of immunoreactive (ir)-inhibin, gonadotropins and steroid hormones during the ovulatory cycle of the duck. J. Reprod. Dev. 51: 353-358. 